\title{
Metastatic Infiltrating Bladder Urothelial Carcinoma with Giant Cells
}

National Cancer Institute

\section{Source}

National Cancer Institute. Metastatic Infiltrating Bladder Urothelial Carcinoma with Giant

Cells. NCI Thesaurus. Code C157769.

Bladder giant cell variant urothelial carcinoma that has spread to another anatomical site. 